\title{
Pengaruh Return On Equity Dan Debt To Equity Ratio Terhadap Perubahan Laba Pada Perusahaan Ritel Yang Terdaftar Di Bursa Efek Indonesia Tahun 2014-2019
}

\author{
Eka Sri Rahmawati ${ }^{1}$, Nanu Hasanuh ${ }^{2}$ \\ Fakultas Ekonomi, Universitas Singaperbangsa Karawang \\ e-mail: ekasrir01@gmail.com ${ }^{1}$, nanu.hasanuh@fe.unsika.ac.id ${ }^{2}$
}

\section{ARTICLES}

\section{ABSTRACT}

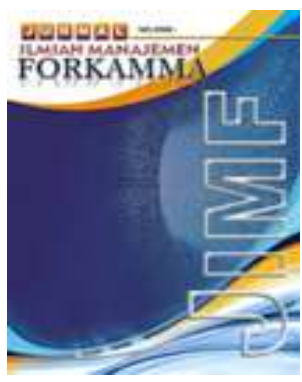

\section{JURNAL ILMIAH MANAJEMEN FORKAMMA}

\author{
Vol.4, No.2, Maret 2021 \\ Halaman : $205-214$ \\ (C) LPPM \& FORKAMMA
}

Prodi Magister Manajemen UNVERSITAS PAMULANG

$$
\begin{array}{cc}
\text { ISSN (online) } & : 2599-171 X \\
\text { ISSN (print) } & : 2598-9545
\end{array}
$$

\section{Keyword :}

Debt to Equity Ratio;Perubahan Laba; Return on Equity

JEL. classification :

O15,

\section{Contact Author :}

$$
\begin{gathered}
\text { PRODI } \\
\text { MAGISTER MANAJEMEN \& } \\
\text { FORKAMMA UNPAM } \\
\text { JL.Surya Kencana No.1 Pamulang } \\
\text { Tangerang Selatan - Banten } \\
\text { Telp. (021) 7412566, Fax (021) } 7412491 \\
\text { Email : } \\
\text { jurnalforkamma.unpam@gmail.com }
\end{gathered}
$$

Sektor perdagangan eceran atau eceran di Indonesia berkembang dengan cepat sehingga memicu berkembangnya e-commerce di Indonesia. Konsumen mulai berpaling dari belanja secara tradisional beralih ke situs perbelanjaan online untuk berbelanja karena dinilai lebih praktis dalam berbelanja yang menyebabkan terjadinya penurunan Laba pada perusahaan eceran, sehingga banyak peeceran yang menutup usahanya. Suatu perusahaan dapat dikatakan sukses atau berhasil ketika perusahan dapat menghasilkan Laba. profit dibutuhkan untuk kesinambungan hidup perusahaan. Hasil dari riset ini memperlihatkan jika sebagai parsial Return On Equity berpengaruh kepada transformasi laba pada perusahaan ritel yang tertera di BEI. Sebaliknya DER tidak mempengaruhi tertera transformasi laba pada industri eceran yang tertera di BEI. Sebagai simultan ROE dan DER secara bersamaan berpengaruh kepada transformasi profit pada perusahaan eceran yang tertera di BEI

The retail or retail trade sector in Indonesia is growing rapidly, triggering the development of e-commerce in Indonesia. Consumers are starting to turn away from traditional shopping to switch to online shopping sites to shop because they are considered more practical in shopping which causes a decrease in profits at retail companies, so that many retailers have closed their businesses. A company can be said to be successful or successful when the company can generate profits. profit is needed for the sustainability of the company's life. The results of this research show that as a partial Return On Equity has an effect on profit transformation in retail companies listed in IDX. Meanwhile, DER does not affect the profit transformation in the retail industry listed in IDX. Simultaneously, simultaneous ROE and DER simultaneously affect the transformation of profit at retail companies listed in IDX. 


\section{A. PENDAHULUAN}

Sektor perdagangan ritel atau eceran di Indonesia meningkat dengan cepat dan menimbulkan persaingan ketat antar perusahaan yang bekerja dalam industri ini. perdangan eceran di indonesia diklasifikasikan menjadi eceran tradisional dan eceran modern. Ritel modern menggambarkan perkembangan dari eceran tradisional, praktiknya memakai rancangan modern serta mengikuti pengkembangan gaya hidup pelanggan. Ritel modern ditaksir lebih efisien serta aman buat berbelanja dibanding dengan eceran konvensional.

Perkembangan eceran mengalami perubahan setiap tahun. Penyebabnya adalah perubahan, perubahan adalah teknologi yang berkembang pesat yang memicu berkembangnya e-commerce di Indonesia. E-commerce atau electronic commerce menjadi salah satu wadah yang dimanfaatkan oleh sebagian pelaku usaha untuk memasarkan produk mereka jual secara online. Dengan adanya e-commerse, perilaku konsumen lambat laun mengalami perubahan yang berdampak pada pertumbuhan industri eceran. Konsumen mulai berpaling dari belanja secara tradisional dengan mendatangi toko beralih ke situs perbelanjaan online untuk berbelanja yang dinilai lebih praktis dalam berbelanja.

Akibat dari perubahan pola belanja masyarakat tersebut menyebabkan terjadinya penurunan Laba yang diperoleh perusahaan ritel atau eceran, sehingga banyak peeceran yang menutup beberapa gerai bahkan sampai menutup usahanya.

Salah satu indikator yang dapat menyatakan suatu perusahaan sukses atau berhasil yaitu perusahaan dapat menghasilkan laba. Laba diperlukan untuk kelangsungan hidup perusahaan. Laba yang dihasilkan dapat berubah setiap tahunnnya. Perubahan Laba atau peningkatan dan penurunan Laba bergantung pada seberapa besar tingkat penjualan yang dapat dilakukan perusahaan. Berikut merupakan grafik Laba perusahaan eceran yang tercantum pada BEI dari tahun 2014 hingga tahun 2019:

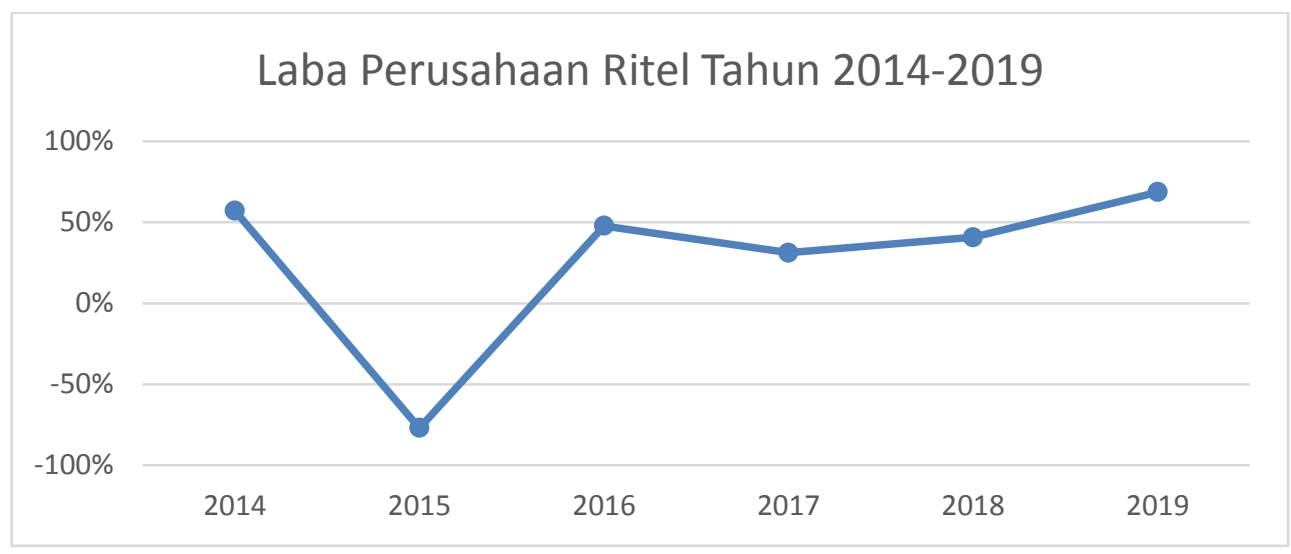

Gambar 1

Laba Perusahaan Eceran Tahun 2014-2019

Sumber: Data diolah peneliti (www.idx.co.id), 2021

Menurut gambar 1 terlihat bahwa Laba mengalami perubahan setiap tahunnya. Pada tahun 2015 perolehan Laba mengalami penurunan menjadi $-77 \%$ dari yang sebelumnya sebesar $57 \%$ di tahun 2014 . Kemudian mengalami penurunan kembali dari $48 \%$ pada tahun 2016 menjadi $31 \%$ di tahun 2017. Lalu mengalami peningkatan di tahun 2018 menjadi 41\%, pada tahun 2019 naik kembali menjadi 69\%. Penurunan Laba yang drastis 
pada tahun 2015 diakibatkan oleh adanya pelemahan ekonomi yaitu tingginya nilai tukar uang yang menyebabkan kenaikan harga barang sehingga terjadi penurunan minat belanja masyarakat.

\section{B. KAJIAN LITERATUR}

\section{Laba}

Laba adalah mendapatkan profit tertinggi merupakan salah satu dorongan penting dalam melaksanakan sesuatu perusahaan. Operasi yang profitabel merupakan sesuatu keharusan untuk perusahaan untuk dapat bertahan serta maju dalam bagian usahanya itu. Untuk menaikkan penampilan upaya sesuatu industri wajib sanggup menciptakan laba. Laba yang didapat industri memiliki kedudukan yang berguna untuk kesinambungan perusahaan karena dipakai untuk evaluasi industri yang dijadikan dasar pemungutan ketetapan pemodalan serta meramalkan transformasi profit dimasa depan (Handayani \& Nugroho, 2018).

Laba yakni hasil seluruh staf dalam sesuatu perusahaan yang diklaim dalam bentuk nilai moneter adalah perbedaan positif antara penghasilan dikurangi beban (Expenses) (Darsono \& Purwanti, 2008).

\section{Perubahan Laba}

Perubahan laba merupakan perbandingan tahunan kenaikan serta penyusutan laba yang didapat perusahaan. Pergantian laba berlangsung di sesuatu perusahaan sebagai dasar untuk penanam modal buat memastikan apakah mereka akan melaksanakan pembelian, pemasaran ataupun menahan pemodalan mereka (Suharti \& Kalim, 2019).

Transformasi laba dapat memaparkan kemampuan perusahaan khususnya keahlian perusahaan dalam menjaga posisi ekonominya di tengah perkembangan ekonomi serta zona usahanya. Kemampuan industri bisa dibilang bagus bila hadapi transformasi laba yang positif (bertambah), sebaliknya bila perubahan laba perusahaan menyusut, hingga bisa dibilang kalau kemampuan perusahaan tengah alami penyusutan kemampuan (Kasmir, 2016).

\section{Return On Equity}

Return On Equity (ROE) memperlihatkan komparasi deskripsi keterampilan perusahaan dalam menciptakan laba. Dengan metode membandingkan laba bersih setelah pajak dengan modal (Sirait, 2017).

Return On Equity ialah komparasi untuk menimbang laba bersih setelah pajak dengan modal sendiri. Perbandingan ini membuktikan kemampuan pemanfaatan modal sendiri. Perbandingan nya semakin besar perbandingan ini, semakin baik (Kasmir, 2018).

$$
\text { Return On Equity }=\frac{\text { Laba setelah pajak }}{\text { Total Ekuitas }}
$$

\section{Debt to Equity Ratio}

Debt to Equity Ratio (DER) yaitu komparasi yang menyamakan pinjaman serta modal dalam pendanaan perusahaan serta memperlihatkan keahlian modal sendiri dalam memenuhi kewajibannya (Sujarweni, 2017).

$D E R$ menggambarkan perbandingan untuk memperhitungkan pinjaman dengan modal. Perbandingan semua pinjaman, termasuk pinjaman lancar serta seluruh modal. Perbandingan ini bermanfaat untuk mengenali jumlah anggaran yang diadakan peminjam (penagih) dengan pemilik industri. Dengan tutur lain, perbandingan ini berperan buat mengenali modal sendiri yang menjadi jaminan (Kasmir, 2018). 


$$
\text { DER }=\frac{\text { Total Utang }}{\text { Total Modal }}
$$

\section{Kerangka Pemikiran}

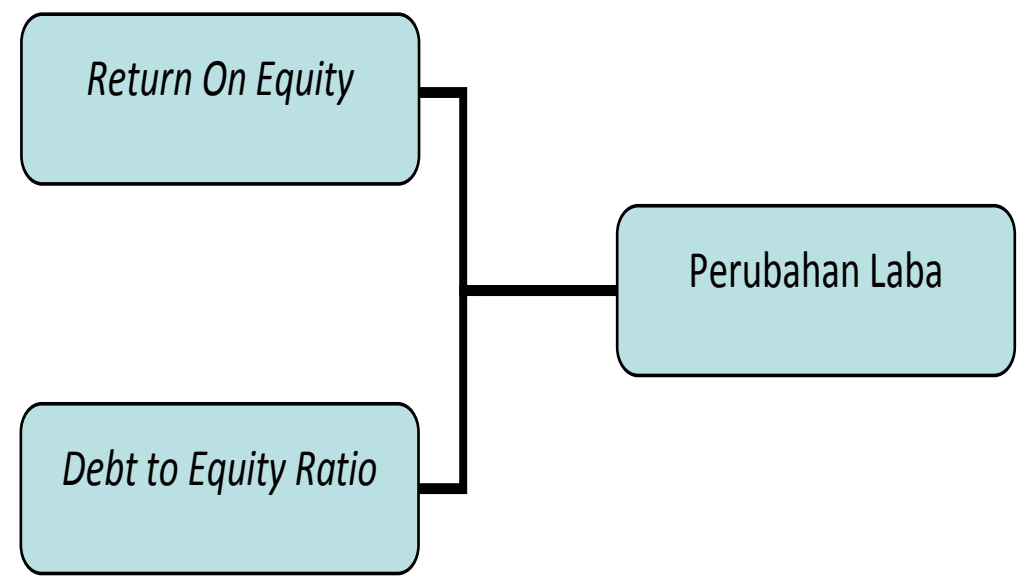

Sumber: Data diolah peneliti 2021

\section{Hipotesis Penelitian}

H1 : ROE mempunyai pengaruh kepada perubahan Laba.

$\mathrm{H} 2$ : DER mempunyai pengaruh kepada perubahan Laba.

H3 : ROE dan DER mempunyai pengaruh kepada perubahan Laba.

\section{METODOLOGI PENELITIAN}

Metodologi yang dipakai pada penelitian ini adalah teknik deskriptif dengan pendekatan kuantitatif. Variabel dalam penelitian ini antara lain :

- $\quad R O E(X 1)$

- $\quad D E R(\mathrm{X} 2)$

- Perubahan Laba $(\mathrm{Y})$

Populasi dalam studi ini berjumlah 27 perusahaan yang ialah perusahaan sektor Perdagangan Ritel yang tercatat di BEI Tahun 2014- 2019. Tata cara yang dipakai untuk menentukan percontoh dalam penelitian ini ialah metode purposive sampling, maka didapat 10 perusahaan yang sesuai dengan penelitian.

Kategori data yang dipakai pada penelitian ini yaitu data kuantitatif serta sumber data yang dipakai ialah data sekunder. Berbentuk laporan finansial perusahaan sektor perdagangan ritel atau eceran yang tercatat di BEI terunduh pada laman www. idx. co. id pada rentang waktu 2014- 2019.

Metode analisa data adalah analisa statistik deskriptif, uji coba asumsi klasik, analisa regresi linear berganda serta pengujian hipotesis. 


\section{HASIL DAN PEMBAHASAN}

\section{Uji Normalitas}

Uji Normalitas adalah uji yang dilakukan untuk mengetahui apakah data-data yang digunakan dalam penelitian ini terdistribusi normal atau tidak.

Table 1

Hasil Uji Coba Normalitas

\begin{tabular}{llr}
\hline & \multicolumn{2}{c}{$\begin{array}{r}\text { Unstandardi } \\
\text { zed Residual }\end{array}$} \\
\hline $\mathrm{N}$ & & 60 \\
\hline Normal Parameters $^{\text {a,b }}$ & Mean &, 0000000 \\
\cline { 2 - 3 } & $\begin{array}{l}\text { Std. } \\
\text { Deviation }\end{array}$ & 58,89854225 \\
\hline Most Extreme & Absolute &, 113 \\
\cline { 2 - 3 } Differences & Positive &, 113 \\
\cline { 2 - 3 } & Negative &,- 070 \\
\hline Test Statistic & &, 113 \\
\hline Asymp. Sig. (2-tailed) & &, $054^{\mathrm{c}}$ \\
\hline \multicolumn{2}{c}{ Sumber : Data diolah SPSS 22.0 (2021) }
\end{tabular}

Berdasarkan tabel 1 menunjukkan bahwa poin relevan sebesar 0,054 . Nilai relevan itu berada diatas 0,05 , maka dapat dirumuskan bahwa informasi terdistribusi normal. Tidak hanya memakai One-Sample Kolmogrov-Smirnov Test uji coba normalitas dapat pula memakai uji coba grafik histogram. Grafik histogram mengubah informasi yang diteliti jadi diagram batang. Bila grafik menyamai ataupun membuat kurva lonceng (bell shape curve) maka, informasi itu dinyatakan terdistribusi normal. Berikut ialah hasil grafik Histogram pada penelitian ini:

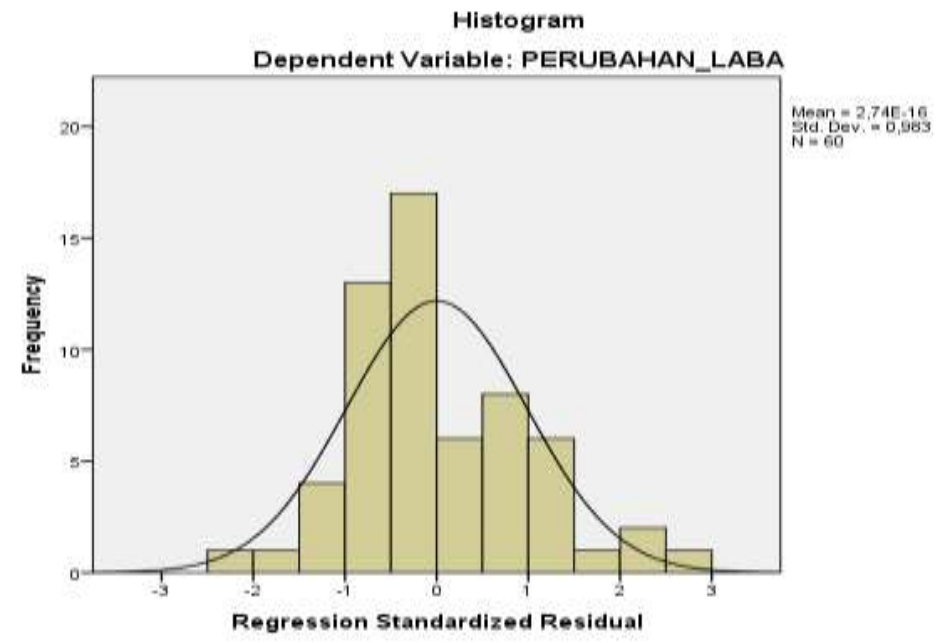

Gambar 2 Grafik Histogram

Sumber : Data diolah SPSS 22.0 (2021) 
Menurut Gambar 2 Grafik histogram membentuk kurva normal (bell shaped curve) dapat dikatakan terdistribusi normal.

\section{Uji Multikoleniaritas}

Uji multikolinieritas mempunyai tujuan untuk mencari tahu apakah bentuk regresi tedapat hubungan antar variabel bebas( independen).

Tabel 2

Hasil Uji Multikolinearitas

\begin{tabular}{|c|c|c|c|}
\hline \multirow[b]{2}{*}{ Model } & & \multicolumn{2}{|c|}{ Collinearity Statistics } \\
\hline & & Tolerance & VIF \\
\hline \multirow[t]{3}{*}{1} & (Constant) & & \\
\hline & ROE & ,998 & 1,002 \\
\hline & DER & ,998 & 1,002 \\
\hline
\end{tabular}

Berdasarkan Tabel 2 Nilai tolerance ROE dan DER sebesar 0,998 menunjukan bahwa nilai tolerance lebih besar dari 0,10. Nilai VIF ROE dan DER sebesar 1,002 membuktikan jika nilai VIF kurang dari 10,0. Hasil tolerance dan VIF itu membuktikan jika dalam bentuk regresi tidak berlangsung multikolinieritas.

\section{Uji Autokorelasi}

uji autokorelasi mempunyai tujuan menguji dalam bentuk regresi linear apakah terdapat hubungan antara periode $t$ dengan periode $\mathrm{t}-1$ ( sebelumnya).

Tabel 3

Hasil Uji Autokorelasi

\begin{tabular}{|c|c|c|c|c|c|}
\hline Model & $\mathbf{R}$ & R Square & $\begin{array}{c}\text { Adjusted R } \\
\text { Square }\end{array}$ & $\begin{array}{l}\text { Std. Error of } \\
\text { the Estimate }\end{array}$ & $\begin{array}{l}\text { Durbin- } \\
\text { Watson }\end{array}$ \\
\hline 1 &, $494^{a}$ &, 244 &, 217 & 59,92294 & 1,705 \\
\hline
\end{tabular}

Berlandaskan Tabel 3 Hasil uji coba autokorelasi dihasilkan nilai Durbin-Watson (DW hitung) sebesar 1,705. Nilai dU (batas atas) yang dihasilkan dari tabel Durbin-Watson dengan jumlah $\mathrm{N}$ sebesar 60 , angka signifikan sebesar $5 \%$ dan variabel independent sebesar 2 sebesar 1,658. Nilai yang didapat dari hasil 4-dU (batas atas) sebesar 2,3482. Nilai autokorelasi dalam bentuk regresi ini merupakan 1,658 $<1,705<2,3482$. Dari hasil itu memenuhi ketentuan tidak berlangsung autokorelasi positif atau negatif, hingga bisa disimpulkan jika pada bentuk regresi itu tidak berlangsung autokorelasi positif atau negatif. 


\section{Uji Heteroskedastisitas}

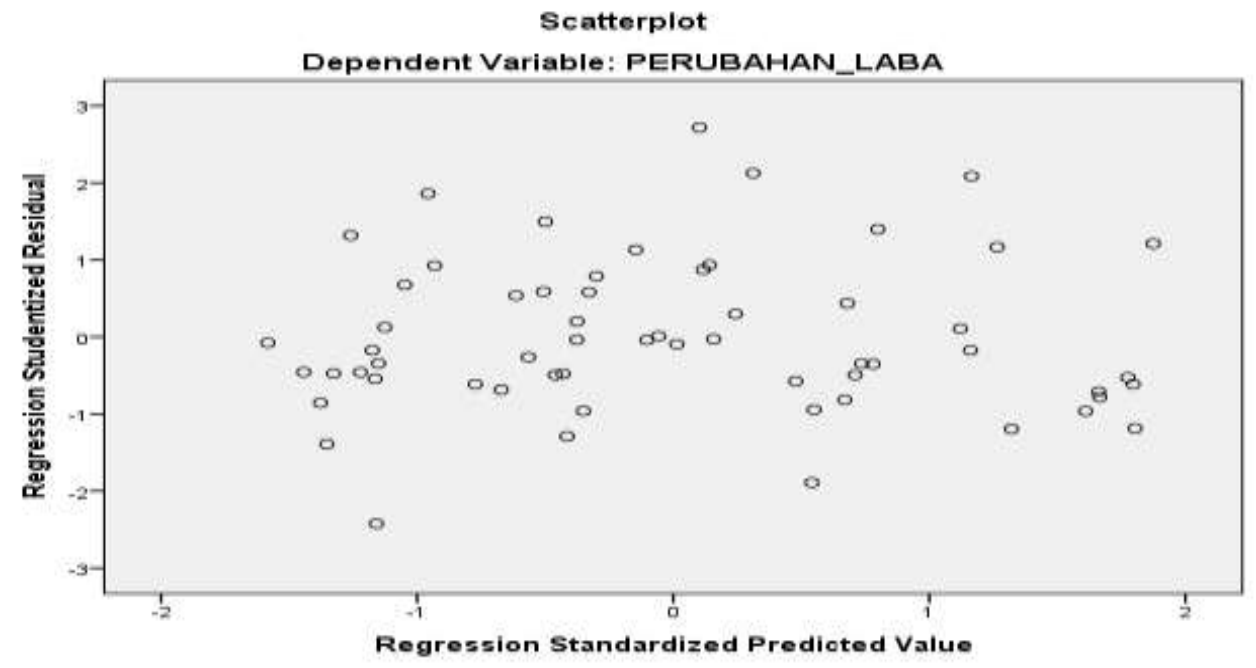

Gambar 3 Diagram Scatterplot

Sumber : Data diolah SPSS 22.0 (2021)

Menurut pada gambar 3 tampak jika data tersiar secara random diatas dan pada sumbu $Y$ di bawah 0 tidak menghasilkan bentuk khusus. Bersumber pada hal tersebut, sehingga model regresi yang dipakai dalam penelitian ini tidak berlangsung heteroskedastisitas.

\section{Uji Analisa Regresi Linier Berganda}

Tabel 4

Hasil Uji Coba Analisa Regresi Linier Berganda

\begin{tabular}{|c|c|c|c|}
\hline \multirow{2}{*}{\multicolumn{2}{|c|}{ Model }} & \multicolumn{2}{|c|}{$\begin{array}{l}\text { Unstandardized } \\
\text { Coefficients }\end{array}$} \\
\hline & & B & Std. Error \\
\hline \multirow[t]{3}{*}{1} & (Constant) & $-51,331$ & 17,404 \\
\hline & ROE & 4,681 & 1,103 \\
\hline & DER &,- 047 & ,061 \\
\hline
\end{tabular}

Menurut tabel 4 hasil model persamaan analisa regresi linear berganda adalah sebagai berikut:

$$
\text { PERUBAHAN LABA }=-5,331+4,681-0,047+e
$$

\section{Uji Coba Koefisien Determinasi}

Koefisien determinasi merupakan angka yang menerangkan ataupun dibubuhkan untuk mengetahui kontribusi yang dihasilkan oleh satu atau lebih variabel bebas kepada variabel terikat. 
Tabel 5

Uji Coba Koefisien Determinasi

\begin{tabular}{llrrrr}
\hline Model & R & R Square & $\begin{array}{c}\text { Adjusted R } \\
\text { Square }\end{array}$ & $\begin{array}{c}\text { Std. Error of } \\
\text { the Estimate }\end{array}$ & $\begin{array}{c}\text { Durbin- } \\
\text { Watson }\end{array}$ \\
\hline 1 &, $494^{\text {a }}$ &, 244 &, 217 & 59,92294 & 1,705 \\
\hline \multicolumn{7}{c}{ Sumber: Data diolah SPSS $22.0(2021)$}
\end{tabular}

Bersumber pada pada tabel 5 , hasil angka $R$ Square yang dihasilkan yaitu sebesar 0.244 atau $24,4 \%$. Hal ini menujukkan jika dampak ROE dan DER sebesar $24,4 \%$ pada Perubahan laba. Sedangkan sisanya sebesar $73,6 \%$ terpengaruhi variabel lain.

\section{Uji t (Parsial)}

uji ini bertujuan mengenali besar dampak varibael bebas terhadap variabel terikat secara parsial.

Tabel 6

Uji Coba t (Parsial)

\begin{tabular}{llrr}
\hline & Model & \multicolumn{1}{c}{ T } & \multicolumn{1}{c}{ Sig. } \\
\hline 1 & (Constant) & $-2,949$ &, 005 \\
ROE & 4,245 &, 000 \\
DER &,- 773 &, 443 \\
\hline \multicolumn{2}{r}{ Sumber: Data diolah SPSS 22.0 (2021) }
\end{tabular}

Berlandaskan hasil yang terdapat pada tabel 6 uji coba t dapat dijabarkan sebagai berikut:

1. Pengaruh ROE kepada Perubahan Laba

Berlandaskan hasil percobaan didapat nilai signifikan $0,00<0$, 05. maka dapat dikatakan HO ditolak dan $\mathrm{H} 1$ diterima. Dengan seperti itu, ROE mempengaruhi kepada Perubahan Laba. Hasil percobaan ini selaras dengan riset yang dicoba oleh Ghazali Syamni dan Martunis (2013) yang membuktikan jika ROE secara parsial mempengaruhi kepada perubahan laba.

2. Pengaruh DER kepada Perubahan Laba

Menurut uji coba dihasilkan nilai signifikan $0,443>0$, 05. maka dapat disebut Ho diterima serta $\mathrm{H} 2$ ditolak. Dengan demikian, DER tidak berpengaruh kepada Perubahan Laba. Dan hasil percobaan ini searah dengan riset yang dicoba oleh Devi Riana dan Lucia Ari Diyani (2016) memperlihatkan jika DER tidak mempengaruhi kepada pergantian laba.

\section{Uji F (Simultan)}

Pengujian ini mempunyai tujuan untuk mengenali berapa besar dampak variabel bebas kepada variabel terikat dengan cara simultan atau besamaan.

Tabel 7

Hasil Uji F (Simultan)

\begin{tabular}{|c|c|c|c|c|c|c|}
\hline Model & & $\begin{array}{l}\text { Sum of } \\
\text { Squares }\end{array}$ & Df & $\begin{array}{c}\text { Mean } \\
\text { Square }\end{array}$ & $\mathbf{F}$ & Sig. \\
\hline \multirow[t]{3}{*}{1} & Regression & 65926,277 & 2 & 32963,139 & 9,180 &, $000^{\mathrm{b}}$ \\
\hline & Residual & 204673,258 & 57 & 3590,759 & & \\
\hline & Total & 270599,535 & 59 & & & \\
\hline
\end{tabular}


Menurut tabel diatas hasil yang ada pada tabel 7 diketahui jika nilai signifikan $\mathrm{F}$ sebesar 0, 000 dimana nilai itu tdak lebih besar dari 0, 05 maka dapat disebutkan $\mathrm{H} 3$ diperoleh. Dengan seperti itu dapat disimpulkan jika ROE dan DER secara bersama-sama berpengaruh pada Perubahn laba. Dan hasil riset ini selaras dengan riset yang dilakukan oleh Anessa Musfitria (2016) yang menunjukkan jika ROE dan DER secara bersamaan atau simultan mempengaruhi perubahan laba

\section{E. KESIMPULAN}

Menurut hasil studi dan pembahasan perihal dampak ROE dan DER pada perubahan laba di perusahaan eceran yang tercatat di BEl tahun 2014-2019, sehingga bisa disimpulkan selaku berikut:

1. ROE dengan cara parsial mempengaruhi kepada perubahan laba pada perusahaan eceran yang tercatat di BEI tahun 2014-2019. Dimana nilai signifikan yang didapat dalam uji t yaitu $0,000<0,05$.

2. DER dengan cara parsial tidak mempengaruhi kepada perubahan laba pada perusahaan ritel atau eceran yang tercatat di BEI tahun 2014-2019. Dimana nilai relevan yang didapat dalam uji $\mathrm{t}$ adalah $0,443>0,05$.

3. Nilai signifikan $\mathrm{F}$ didapat adalah sebesar 0,000 dimana nilai itu tidak lebih besar dari 0,05 maka dapat disimpulkan ROE, dan DER dengan cara bersamaan mempengaruhi kepada perubahan laba pada Perusahaan ritel atau eceran yang tercatat di BEI tahun 2014-2019.

Menurut kesimpulan yang terpaparkan, maka saran peneliti adalah sebagai berikut:

1. Menambahkan variabel bebas yang dapat mempengaruhi perubahan Laba.

2. Menambah jumlah sampel penelitian, semakin banyak jumlah sampel diharapkan hasil penelitian menggambarkan keseluruhan perubahan Laba perusahaan.

\section{DAFTAR PUSTAKA}

Abdul Kadim, K., \& Nardi Sunardi, S. (2018). Determinant Of Company's Likuidity And It's Implications On Financial's Performance Of Ritail Trade Company's In Indonesia At The Period Of 2008-2017. Global and Stockhastic Analysis, 5(7), 235-247.

Darsono, \& Purwanti, A. (2008). Penganggaran Perusahaan. Jakarta: Mitra Wacana Media.

Ghazali, Imam. (2018). Aplikasi analisis multivariate dengan program ibm SPSS 25 (9 ed). Semarang: Undip.

Hakim, L., Sunardi, N. (2017). Determinant of leverage and it's implication on company value of real estate and property sector listing in IDX period of 2011-2015. Man in India, 97(24), pp. 131-148.

Hanafi, M., \& Halim, A. (2009). Analisis Laporan Keuangan. Yogyakarta: BPFE.

Handayani, A. T., \& Nugroho, B. (2018) Dampak Rasio Keuangan terhadap Perubahan Laba pada Perusahaan Makanan dan Minuman. Jurnal Online Insan Akuntan, 3(2).

Hantono, \& Rahmi, N. U, (2018). Pengantar Akuntansi. Yogyakarta: CV Budi Utama. 
Kasmir. (2016). Analisis Laporan Keuangan. Jakarta: Raja Grafindo Persada.

Kasmir. (2018). Analisis Laporan Keuangan. Jakarta: PT RajaGrafindo Persada.

Martani, D., Siregar, S. V., \& Wardhani, R. (2016). Akuntansi Keuangan Menengah Berbasis PSAK (2 ed.). Jakarta: Salemba Empat.

Musfitria, A. (2016). Pengaruh Rasio Keuangan Terhadap Perubahan Laba Pada Perusahaan Manufaktur Yang Terdaftar Di Bursa Efek Indonesia (BEI) Periode 2012-2014. Jurnal Gici, 6(1).

Nardi Sunardi Et Al (2020). Determinants of Debt Policy and Company's Performance, International Journal of Economics and Business Administration Volume VIII Issue 4, 204-213

Nurmalasari, T. (2012). Analisis Pengaruh Rasio Keuangan Terhadap Perubahan Laba Pada Perusahaan Manufaktur Yang Terdaftar Di Bursa Efek Indonesia (BEl).

Prihartono, A., Setiyaningsih, T. A., \& Rahayu, D. P. (2018). Pengantar Akuntansi Berbasis PSAK Terbaru. Bogor: In Media.

Puspaningrum, R. C., Suseno, Y. D., \& Sriwidodo, U. (2018). Analisis Pengaruh Rasio Keuangan Terhadap Pertumbuhan Laba Perusahaan (Studi Empiris pada Perusahaan Food \& Beverages yang Terdaftar di BEI Tahun 2009 - 2013). EJurnal Unisri .

Riana, D., \& Diyani, L. A. (2016). Pengaruh Rasio Keuangan dalam Memprediksi Perubahan Laba pada Industri Farmasi (Studi Kasus pada BEI Tahun 2011 2014). Jurnal Online Insan Akuntan, 1(1).

Samryn, L. (2012). Akuntansi Manajemen. Jakarta: Kencana.

Siregar, S., 2015. Statistik Parametrik untuk Penelitian Kuantitatif : Dilengkapi dengan Perhitungan Manual dan Aplikasi SPPS Versi 17. Jakarta: PT Bumi Aksara.

Suharti, \& Kalim, D. A. (2019). Analisis Pengaruh Current Ratio, Debt to Equity Ratio, Net Profit Margin, dan Total Assets Turnover terhadap Perubahan Laba Perusahaan Pertambangan Batu Bara yang Terdaftar di BEl Tahun 2013-2017. Bilancia, 3(1).

Sujarweni, V. W. (2017). Manajemen Keuangan Teori, Aplikasi dan Hasil Penelitian. Yogyakarta: Pustaka Baru Press.

Sunardi, N., \& Lesmana, R. (2020). Konsep Icepower (Wiramadu) sebagai Solusi Wirausaha menuju Desa Sejahtra Mandiri (DMS) pada Masa Pandemi Covid19. JIMF (Jurnal IImiah Manajemen Forkamma), 4(1).

Syamni, G., \& Martunis. (2013). Pengaruh OPM, ROE dan ROA terhadap Perubahan Laba Perusahaan Telkom. Jurnal Kebangsaan, 2(4). 